\title{
What Conditions May Foster an Industrial Development Strategy from Extractive Industries?
}

\section{Mancini, L. \\ Paz, María J. mjpazant@ucm.es}

\begin{abstract}
Our work provides a selective survey of the literature on the relation between natural resources and industrialization, with a focus on extractive industries. The paper consists of three sections. First, it discusses the main problems identified by the scholars in relation to the abundance of natural resources. Second, it addresses two dimensions of the nexus between natural resources and industrial development: a fiscal one and a productive one. Third, it critically examines the two dimensions in order to find the conditions needed to set up a strategy of industrial development applicable to the extractive industries. Then, it briefly discusses some relevant issues partially neglected in early literature, and then suggests insights for further research.
\end{abstract}

Key words: Industrialization · Extractive Industries $\cdot$ Economic Development $\cdot$ Dutch Disease $\cdot$ Resource Curse

\section{Introduction}

The influence of an endowment of natural resources (NR hereafter) in shaping the economic, social, and political life of countries has been widely debated for decades. Recently, new works have emerged questioning the thesis known as resource curse, which posits a negative relationship between abundance of NR and country economic performance. Countering this argument, many scholars have pointed that this relationship is not always negative, whereas the political and institutional framework can be determinant.

Since 2000, the academic debate has gained prominence in a context earmarked by a global commodity boom which has also encouraged the proliferation of new economic strategies related to the exploitation of NR in developing countries. That has been especially the case of extractive industries, which have been strongly affected by rising prices and an increased demand during 2000-2014. Though since 2013 the upward trend has been reversed and the volatility of prices has increased, the debate over these 
strategies is still open. That is due to the fact that, alongside the resource boom, two factors have contributed to the spreading of such strategies: (1) the difficulty in imitating the Asian model of industrialization in African and Latin American developing countries, and (2) a critical review of the "Washington Consensus" vis-a-vis a "new" emergent consensus that looks more favorably to governmental intervention and industrial policy.

Given this background, found in both academic and political discourse, we operate from a presumption that the resource curse is neither inevitable nor irreversible. Precisely for this reason, our work assumes that it is possible to define a strategy of industrial development from NR. From here, the paper addresses two research questions, as follows: (1) what are the main economic problems that have hindered the industrialization in some resource-rich countries? And, taking into account these problems, (2) what conditions may foster a strategy of industrial development from NR?

The purpose of our research is to answer both questions through a critical review of the most significant literature on the topic. Our first aim is to synthesize and compare the main contributions, thus reflecting the current state of thought on the subject. It must be noted that the literature on NR is quite extensive and dispersed across different approaches, even within the same line of economic thought. Therefore, the selection of references, a key part of this study, has been done with the explicit intention of extracting the essential argument of each approach; that is, the most pertinent to the research questions. $^{1}$

This paper differs from previous researches going beyond a critical review of the resource curse literature (Di John, 2011) by interpreting the industrialization as an essential (though not unique) part of the economic development. Moreover, while we share early contributions on the relevance of domestic policy decisions in determining the impact of the exploitation of NR (Saad-Filho and Weeks, 2013), we move further by looking into what type of conditions and policies may foster a strategy of industrial development in resource-rich developing countries. We argue that sound economic policies should take into account both fiscal and productive dimension.

The paper is organized as follows. Section 1 looks into a critical review of the major problems associated with the exploitation of NR. Our findings leads us to distinguish

\footnotetext{
${ }^{1}$ Though our interest is on extractive industries, we are also taking into account references that analyze natural resources as a whole, since most of the conclusions are also applicable to the extractive industries. Notwithstanding, as we will discuss, when we analyze case studies on specific sectors, our review will be focused on extractive industries.
} 
three fundamental issues: (1) the macroeconomic problems which adversely affect the industrialization (Dutch disease), (2) those aspects associated with rent-seeking, resource dependence, and the distribution of incomes generated by the exploitation of NR (rentism), and (3) the difficulties to develop linkages with the rest of the economy (structuralist concerns).

In Section 2, we seek to identify the economic conditions which should be considered in a resource-based strategy of industrialization. The various contributions have been divided into two main categories: those affecting the productive dimension, and those concerning the fiscal dimension. We found a clear complementarity between these two dimensions, which is the result of an increasing "dialogue" between neostructuralism and neo-institutionalism within the field of development economics.

Finally, Section 3 summarizes the main points of convergence and disagreement among scholars, thereafter synthesizing the answers to the research questions.

\section{Problems Related with Natural Resources Exploitation}

\subsection{Dutch Disease and De-industrialization}

The phenomenon known as the Dutch disease (DD hereafter) is one of the main problems which have been associated with the exploitation of NR. In synthetic form, the DD suggests that a robust expansion of the aggregate income of the productive factor used in the exploitation of energy resources may affect the external competitiveness of other tradable sectors (especially the manufacturing and agriculture); it occurs mainly, but not exclusively, through an appreciation of the real exchange rate.

De-industrialization may result as a consequence of two main mechanisms (Corden and Neary, 1982; Corden, 1984; Krugman, 1987). First, the shrinking of the industry occurs directly, since employment, production, and other resources in the economy begin to move away from the non-booming tradable sector and become oriented toward the resources-intensive industry, assuming that this sector is associated with a relatively higher marginal product of labor resulting from the boom (resource movement effect). On the other hand, the increase of income generated within the economy leads to an appreciation of nominal currency exchange (assuming a positive income elasticity of demand for non-tradable products, the prices in this sector should rise relative to the prices 
of other tradable sectors); moreover, it stimulates the demand for both tradable and nontradable products (consumption effect). ${ }^{2}$

In addition to these two mechanisms, scholars have also highlighted that the DD may debilitate the economic growth because the shrinking in the manufacturing affects a key sector of the economy where the learning-by-doing process takes place. Assuming that workers can move to the booming energy-intensive sector, the resulting crowding-out of their training would result in a progressive erosion of the human capital present in the economy (Kim, 1998; Bravo-Ortega and De Gregorio, 2005).

Scholars have further developed the investigation of the DD through the incorporation of more sophisticated theoretical models (Bruno and Sachs, 1982). It has been taken into account a more proactive role of macroeconomic intervention considering, for instance, the introduction of public subsidies to sustain the tradable sector negatively affected by the DD (van Wijnbergen, 1984; Gelb et al., 1988; Gylfason, 2001).

Two critical aspects deserve a special attention. First, the copious research that has been developed around the phenomenon of the DD has not reached a wide and robust consensus on whether all the mechanisms depicted in the theoretical models will ultimately arise and on how they actually interact with each other in a specific economic context. Some scholars prefer to stress the currency exchange effects (Caballero and Lorenzoni, 2007) whereas they do not reach a conclusive consensus on the empirical evidence vis-a-vis the overall impact of the DD, especially in terms of economic growth effects through real exchange rate appreciation (Magud and Sosa, 2010).

The second critical point is the consideration that the economic effects are essentially determined by market mechanisms, without taking into proper account the influence of the institutional framework and the specific productive structure. Hence, from this relative disregard to the institutions and the specific productive structure derives a difficulty of pure macroeconomic models to understand and explain why DD materializes in some countries but not in others (Smith, 2007), ${ }^{3}$ and what implications this effect has for

2 Assuming that the price of the former is determined by the international market (earliest models focused on small economies), the expansion of the demand may result in an increase of imports. Hence, prices in the non-tradable sector increase, as do input costs and wages, ultimately affecting the export competitiveness.

3 Smith (2007) has compared the cases of Iran and Indonesia. He has demonstrated that, though both countries began late development in the same period, and the oil and gas industry played a similar role in their economies, they experienced different political consequences after the first oil shock. The author has argued that preexisting institutions and State-society relations determine different results when an oil boom occurs. Indeed, Iran and Indonesia significantly differed both in the context of the onset of late development and in the institutional framework prior to the oil boom. Smith (2007) has suggested that 
developing economies which are still on the path of industrialization or which have not been engaged in it yet. Furthermore, the essential theoretical assumptions of the DD contradict the experience of those countries in which the investments in human capital triggered by the exploitation of NR did contribute to foster industrial development (De Ferranti et al., 2002; Wright and Czelusta, 2002).

Pegg's paper (2010) on Botswana is particularly illustrative of the two critical issues noted above. Pegg shows that Botswana "currently suffers from many of the symptoms of the Dutch disease [...] but not for the causal reasons posited in the Dutch disease model” (op.cit. p. 14). The DD symptoms are the result of non-DD factors, particularly Botswana's local circumstances. Moreover, Pegg shows that Botswana has properly managed revenues from diamonds but that, despite this, the economy has not diversified. In addition, Pegg provides a critical element to the discussion by noting that the debate on the DD "might seem superfluous at first glance" (op. Cit 14), taking into account the high levels of per capita growth in Botswana for more than three decades. This calls into question the notion that the problems associated with DD have been key to many resource-rich developing countries.

Fuentes (2009) studied the case of Chile where the exploitation of copper mines is open to the private sector but the government has a large participation in the resource rents through the State-Owned Enterprise. He suggested that Dutch Disease is not inevitable: the Chilean government managed the resource abundance through fiscal discipline and the creation of stabilization funds in a context of good institutional framework.

Our critical review suggests that the proper inclusion of a historical and structural perspective is desirable, especially considering that a poor competitiveness in the nonbooming tradable sector may be associated not only with a real exchange rate appreciation, but also with structural internal deficiencies of a country. Hence, it may be useful to study the degree of influence that the domestic manufacturing sector is able to exercise on the distribution of rents related to the NR in a way to use them to gain more protection from market competition: that would partially attenuate the manifestations of the DD.

two initial conditions influence the type of government regime: strength of political opposition and constraints on patronage rents. 


\subsection{Rentism and the Resource Curse}

In recent decades there has been a proliferation of researches which constitute the body of an extensive literature on the phenomenon generally referred to as resource curse (Auty, 1994). This issue is not new among scholars: early critics had already stressed key problems to foster industrial development in primary economies of the periphery (Prebisch, 1950; Nurkse, 1953). Notwithstanding, most recent research (Atkinson and Hamilton, 2003; Stevens, 2003; Lederman and Maloney, 2008) tends in some way to refer to the seminal work of Sachs and Warner $(1995,2001)$ who have found evidence of an overall negative correlation between that abundance of NR - especially in extractive industries - and economic growth, examining data on a group of selected countries considered to be rich in such resources.

The results of this reinvigorated research have called into question the limitation of some theoretical assumptions of previous literature. Concretely, this neo-institutionalist approach has highlighted the role of institutions in the relation between NR and economic performance. Therefore, the resource curse literature has increasingly incorporated neoinstitutionalist elements, pointing to additional implications beyond the pure macroeconomic ones previously addressed by DD models. In general, neoinstitutionalists focus on the problems associated with a significant increase in income generated from a boom in the resource-intensive sector. Scholars have evidenced the spread of rent-seeking behaviors, as well as the worsening in the institutional and productive relations, which ultimately affect economic growth (Auty, 2001; Torvik, 2002). The rentist interpretation shares some theoretical elements with the public choice theory: the inadequate management of $\mathrm{NR}$ is mainly attributed to the failures of governmental intervention, as well as to the effect of collective action of influential interest groups (Leite and Weidmann, 1999; Tornell and Lane, 1999; Hammond, 2011). Scholars have also pointed to the association of poor economic performance with the presence of authoritarian, corrupted, and predatory governments. ${ }^{4}$ Van der Ploeg (2010) surveyed different hypothesis about the resource curse and considered that 'rapacious' extraction of rents from ER may help to understand how countries that suffers conflicts among different groups stimulates the exploitation of those resources and public

4 The resource abundance has been often found in association with conflicts, civil wars, political instability, and State authoritarianism (Ross, 2001; Collier and Hoeffler, 2004). Nonetheless, this issue will not be addressed in this work, since our objective is focused on analyzing the links between resource abundance and industrialization. For a more detailed analysis on resources and conflict, see Ross (2004). 
investment in projects with little social return. He suggested strengthening the fiscal rules to make the government more responsible on the spending of the resource revenue.

A line of research investigated whether NR can affect institutional quality, considering it as endogenous to resource wealth. Bulte et al. (2005) found empirical evidence that NR negatively affects different measures of institutional quality, suggesting that institutional reform may be necessary to foster economic growth in resource-rich countries. Most recent works on the resource curse have grown out of those views moving toward a less deterministic position in which, although institutions remain an important explanatory factor, scholars have done an additional step toward investigating which institutions may aggravate the alleged curse. Mehlum et al. (2006) argue that the quality of institutions affects the result of NR on aggregate income. Similarly, Robinson et al. (2006) argue that countries benefit from a resource boom only when state institutions are accountable. Despite further research along that perspective, the evidence has not reached yet a solid consensus. Different critics have been raised pointing at the methodology of research as well as the conceptual framework adopted in the investigation of resource curse. Among them, the often-used concept of institutional quality itself has been challenged (Brunnschweiler, 2008). ${ }^{5}$ Moreover, it must be noted that early literature frequently argued around mere correlations of variables, without ultimately explaining the circular causation between institutional quality and the abundance of NR.

For instance, the indicator used by Sachs and Warner (1995) as a proxy for resource abundance (the ratio of NR exports to GDP) has been often treated as an endogenous variable in the regression models, whereas it is indeed conditioned by those factors which affects economic growth, as the institutional framework. On this point, Brunnschweiler and Bulte (2006) treated resource dependence as endogenous and found that institutions do affect resource dependence even after controlling for resource abundance. They also found that resource abundance positively (not negatively) affects institutional quality and economic growth.

Cross-country analysis and panel data techniques are sensitive to the sample period and countries; they may not allow controlling for historical and institutional characteristics that are correlated with the proxies used for resource abundance. However, to overcome some of these shortcomings, Caselli and Michaels (2009) conducted a within-country research on a dataset of Brazilian municipalities to investigate the effects 
of oil abundance. They found that oil discoveries boost municipal royalties and reported public spending but local living standards do not improve as much as expected. In another within-country study on Zambia copper mining, Lippert (2014) found that an increase in local mineral production positively affect the living standards of household in the constituencies near the mines; that results is confirmed also for people who are not directly involved in the resource extraction. Bhattacharyya and Resosudarno (2015) studied a panel dataset covering 26 provinces of Indonesia over the period 1977-2010. They found that growth in non-mining sectors significantly reduces poverty and inequality, whereas growth in mining sectors seems to have no impact. Furthermore, their study shows that growth acceleration (a period of at least four consecutive years of growth in GDP per capita) in non-mining sectors decreases poverty and inequality; in contrast, the same process in mining sectors intensifies poverty.

Scholars have been increasingly deepening the research of how the institutional framework affects the relation between NR and economic performance. However, it is worth highlighting that few case studies have been developed to investigate the determinants of the historical evolution of the institutions responsible for the fiscal management of resource rents. ${ }^{6}$ That would allow understanding the historical process of formation of the institutional framework and discover the structural reasons behind the management structure of NR in a given country. Though neo-institutionalists do pay attention to the process of institutional change, the focus on this issue in historical and structural terms has been poorly incorporated in.

\subsection{Structuralism and Productive Linkages}

In the 1950s, various scholars focused their investigation on the difficulties to foster industrial development in primary developing economies, pointing at two fundamental problems: (1) the declining tendency of the terms-of-trade relation between primary and manufactured products, and (2) the inter-sectorial dismantling of productive structure in primary countries in the periphery of global economy.

\footnotetext{
6 An interesting exception to this is the study by Haber and Menaldo (2011). Using both country-by-country time series and panel data with country fixed effects, they studied a panel of 168 countries from 1800 to 2006. They found that an increase in resource reliance is not associated with authoritarianism over the long run. Their result has been partially confirmed (for the period before the 1970s) by Andersen and Ross (2014).
} 
In separate works, Prebisch (1950) and Singer (1950) developed the argument of the declining terms-of-trade relation affecting primary exporting economies. Their proposition addressed the consequences of international division of labor in a global capitalist economy, where peripheral regions specialize in the production of primary products for export to the industrialized countries of the center. In their view, the unequal sharing of the fruits of technical progress generated in the manufacturing of the center would have resulted in wage increases relatively higher than the growth of productivity. That would have ultimately conduced to a rise in the prices of industrial goods produced in the center, and to a consequent decline in real terms-of-trade in the periphery. With respect to this issue, Prebisch (1950) also stressed that, though in its view the industrialization of the periphery was not an end itself that process would have been highly relevant to improve the living standards of people in peripheral economies. The key contribution of Latin American structuralists was precisely the incorporation of an historical and structural perspective in a center/periphery vision of the exploitation of NR, while shedding light on the implications of the global economic structure on the institutional framework (Prebisch, 1981).

Thanks to these contributions, most problems associated with the productive dimension of NR exploitation acquired a central relevance; in short, an expansion of manufactured production in the periphery (as part of structural change) could have been possible only through a domestic capital accumulation.

From different views, Latin American structuralists also highlighted the problem of the poor contribution of the primary sector to stimulate the production in other industries, especially the manufacturing. That issue suggests the existence of weak relations between an export-oriented resource-intensive sector and the rest of domestic economy. Several factors explain why extractive industries tend to be enclave sectors, it being possible to differentiate between sector-specific factors and more general factors which tend to be present in developing economies. Among the former, we can highlight the strong presence of foreign capital, the control of production for export, or the specificity of the required technology. Among the latter, we can consider the lack of domestic demand, the underdevelopment of the industrial sector, and the low productivity that favors an enclave model. Moreover, these poor productive linkages across sectors are also deemed to make technology transfer more difficult, exacerbating the already present structural duality in productivity across industries in primary developing countries. 
This model of natural resources exploitation is far from novel, as the historical perspective adopted by the structuralist literature shows. The persistence of this model (even with changes in many cases, despite the implementation of various developmental strategies over the past several decades) shows the magnitude of the challenge to overcome the enclave model.

As discussed, the structuralist perspective addressed the problems to foster industrialization from the exploitation of NR in the framework of center/periphery relations. In this context, the growing internationalization of production and the role of transnational corporations are then taken into consideration to explain the appropriation and use of resource rents by foreign companies. Latin American structuralists and dependentists interpreted this foreign private extraction of surplus as an obstacle to the process of capital accumulation in the periphery, and a factor of deterioration of inter- and intra-sectorial relations between an export-oriented primary sector and the domestic economy. Moreover, considering the role of transnational companies and influential social groups, these scholars evidenced key problems related to the appropriation, distribution, and use of resource rents through a different perspective (Furtado, 1968).

Early scholars, since the pioneering work of Hirschman (1964), focused on linkage effects across sectors and paid attention to the difficulties in fostering fiscal, consumption, and productive linkages from primary sector. A first problematic issue suggested that fiscal linkages would have been an effective mechanism to foster industrial development but only when taxes, royalties, and other revenues generated from the exploitation of NR are channeled toward productive investments in the economy. Second, in an economy at an initial stage of industrialization, the extra-rent generated from primary sector may be partially devoted to the consumption of imported industrial products (hence consumption linkages may be less effective). Finally, in case of the creation of an enclave between primary sector and the rest of the economy, productive linkages may be characterized by a relative detachment across sectors. The idea is that a lack of complementarity across industries may ultimately affect the expansion of domestic market and industrial development.

To sum up, structuralist view raised the attention on the need for an industrial (productive) strategy from NR to overcome the structural dualism of the economy, stimulate linkages and face the (alleged) deterioration of terms-of-trade of primary vis-avis manufactured products. As discussed about resource curse literature, it must be noted that these arguments have been evolving in recent decades. Since the advent of import 
substitution industrialization strategies, developing countries have been moving toward industrial development initiatives which are not merely based in but launched from the exploitation of NR. That is also partially due to the lessons learned from failing attempts of some Latin American and African developing countries to imitate the industrial development model successfully followed by certain Asian economies (which were likewise strongly relying on primary resources).

Table 1. Main problems related with natural resources

\begin{tabular}{|c|c|c|}
\hline Perspectives & Problems & Select scholars \\
\hline \multirow[t]{3}{*}{ Dutch Disease } & $\begin{array}{l}\text { Macroeconomic } \\
\text { mechanisms: resource } \\
\text { movement effect and } \\
\text { spending effect }\end{array}$ & $\begin{array}{l}\text { Bruno and Sachs } \\
\text { (1982); Corden and } \\
\text { Neary (1982); Corden } \\
\text { (1984); Krugman } \\
\text { (1987); Gelb et al. } \\
\text { (1998) }\end{array}$ \\
\hline & $\begin{array}{l}\text { Learning by doing and } \\
\text { human capital }\end{array}$ & $\begin{array}{l}\text { Van Wijnbergen } \\
\text { (1984); Kim (1998); } \\
\text { Gylfason et al. (1999, } \\
\text { 2001); de Ferranti et } \\
\text { al. (2002); Wright and } \\
\text { Czelusta (2002); } \\
\text { Bravo-Ortega and De } \\
\text { Gregorio (2005) }\end{array}$ \\
\hline & Currency exchange & $\begin{array}{l}\text { Caballero and } \\
\text { Lorenzoni (2007); } \\
\text { Magud and Sosa } \\
(2010) \\
\end{array}$ \\
\hline \multirow[t]{4}{*}{$\begin{array}{l}\text { Resource } \\
\text { curse }\end{array}$} & Rentism & $\begin{array}{l}\text { Auty (1994, 2001); } \\
\text { Leite and } \\
\text { Weidmann(1999); } \\
\text { Tornell and Lane } \\
\text { (1999); Torvik (2002); }\end{array}$ \\
\hline & Institutional quality & $\begin{array}{l}\text { Bulte et al. (2005); } \\
\text { Mehlum et al. (2006); } \\
\text { Robinson et al. (2006); } \\
\text { Brunnschweiler } \\
\text { (2008); Hammond } \\
\text { (2011); De Rosa and } \\
\text { Iootty (2012) }\end{array}$ \\
\hline & Economic performance & $\begin{array}{l}\text { Atkinson and } \\
\text { Hamilton (2003); } \\
\text { Stevens (2003); } \\
\text { Leaderman and } \\
\text { Maloney (2008) } \\
\end{array}$ \\
\hline & $\begin{array}{l}\text { Declining terms-of-trade } \\
\text { of primary products and }\end{array}$ & $\begin{array}{l}\text { Prebisch (1950); } \\
\text { Singer (1950) } \\
\end{array}$ \\
\hline
\end{tabular}




\begin{tabular}{|l|l|l|}
\hline $\begin{array}{l}\text { Latin } \\
\text { American } \\
\text { structuralism }\end{array}$ & $\begin{array}{l}\text { insertion in global } \\
\text { economy }\end{array}$ & \\
\cline { 2 - 3 } & $\begin{array}{l}\text { Development of } \\
\text { industrial linkages and } \\
\text { productive structure }\end{array}$ & $\begin{array}{l}\text { Nurkse (1953); } \\
\text { Hirschman (1964); } \\
\end{array}$ \\
& $\begin{array}{l}\text { Furtado (1968); } \\
\text { Prebisch (1981) }\end{array}$ \\
\hline
\end{tabular}

\section{Conditions to Foster an Industrialization Strategy from Natural Resources}

In Section 2 we identified main problems related with the exploitation of NR. Seeking to overcome them, since late 1990s new studies have been oriented to the investigation of the conditions under which the exploitation of NR may boost a process of industrialization that contributes to economic development. A critical review of prominent works in this research area will lead us to identify the key conditions to foster industrial development from NR. Our findings will highlight two major dimensions in which the various works are specifically focused: (1) a productive dimension fundamentally linked to a neostructuralist approach; and (2) a fiscal dimension, often addressed by neo-institutionalist and DD literature.

\subsection{Productive Dimension}

Traditionally, Latin American structuralism has seen the industrialization as a factor of technological progress and a key component of structural change and economic development. More recently, Latin American neo-structuralism has gained prominence in the debate on industrialization, especially in relation with the strategies related with the exploitation of NR. Thus, scholars within that approach have agreed that the key driver of a proper exploitation of NR is to achieve the development of backward and forward linkages (ECLAC, 2008; UNIDO, 2011). These linkages would be capable to encourage the production and export diversification needed to overcome the dualism that often characterizes resource-rich economies (ECLAC, 2005). In addition to those from the ECLAC, other works have provided evidence that the exploitation of NR may generate positive spillovers onto manufacturing through the attraction of investments in new capacity and local support (Ritter, 2001; Sæther at al., 2011).

Forward linkages include the processing, distribution, and marketing of NR; it is in these activities that developing countries may tend to advance their industrial development. Backward (or upstream) linkages involve the supply of inputs, components, 
and equipment manufactured by the industry linked to the oil and gas industry (Teka, 2012). These links are more difficult to achieve than the forward ones, and they are therefore considered essential to foster a process of structural change. Furthermore, some of these sectors are usually more labor intensive than the primary sector, especially when the local supply industry is at incipient stages of development; hence, these activities do play a functional role in countries with abundant labor force (Aragón and Rud, 2011).

Despite the difficulty in achieving such linkages, scholars stressed the need to foster productive agglomerations around NR as engines to boost productive linkages (Ramos, 1999; UNCTAD, 2011). Also, the diversification resulting from the development of these linkages may help to reduce the vulnerability to external shocks that has been determinant in the economic performance of Venezuela and other oil-rich countries (Hausmann and Rodríguez, 2006).

Many cases that show that, under certain circumstances, it is possible to develop those linkages. In Brazil, for example, the inclusion of local content requirements in the bidding round encouraged the growth of the offshore supply chain between 1999 and 2008, generating additional incomes for the national industry worth US\$ 21.5 billion and 875,000 new jobs (Prominp, 2010).

Pérez (2010) has noted that the development of such linkages may contribute to the acquisition of productive and technological capabilities in some sectors that may ultimately boost a new technological revolution. The development of new technologies and innovations from the exploitation of NR turn out to be key conditions to building higher value-added segments in the global value chain. In addition, the diversification of manufacturing production based on technological innovation may boost the learning process and the training of human resources (Teixeira and Ferraro, 2009; Morris et al., 2011). In fact, many investment projects to exploit the NR require the development of specific technologies, which may foster $R \& D$ spending and promote the demand for new capabilities.

If productive linkages are key factors to promote a resource-based industrialization strategy, how are these linkages to be achieved? Three elements have emerged as critical: (1) a sustained growth of the production of NR, which constitutes the springboard of these linkages, (2) an industrial policy that sustain the development of the linkages, and (3) a sustained process of capital accumulation in the domestic economy through new investments. The presence of a structured industrial base, albeit incipient, significantly favors this process whereas the absence of a minimal pre-industrial structure would 
prevent it. That is precisely the challenge faced today by many developing countries with abundant NR.

From the historical experience of Norway, as well as by some other countries, various authors have agreed that State intervention is required to encourage these linkages (Machinea and Vera, 2008; UN-ECA, 2011). In this sense, investment in infrastructure (physical, technological, and communication) and the inclusion of local content measures turn out to be a necessary condition, although sometimes insufficient, for a sound exploitation of NR. The empirical evidence has shown that these factors are strategic to foster productive linkages (Kuramoto, 2000; Adewuyi and Oyejide, 2012). ${ }^{7}$ Moreover, scholars have emphasized the development potential that can be derived from investments in infrastructure at a regional level and have argued in favor of the supranational cooperation among developing countries (AUC, 2012).

Notwithstanding, as Ross (2001) pointed out, some factors such as international trade barriers hinder the productive linkages described above in developing countries. Industrialized countries adopt higher tariffs on processed goods than on the extractive products they import from developing countries.

\subsection{Fiscal Dimension}

Though neo-structuralist approach seems to respond to some issues related with any strategy of industrialization from NR, it does not address all the challenges of insertion in international markets faced by primary-exporting countries. Hence, we suggest complementing the productive dimension with a fiscal dimension that focuses more specifically on the distribution and use of resource rents. Though, as discussed in Section 2, the exploitation of NR gives rise to frequent problems, our research highlight that they do not occur in automatically, nor are they impossible to overcome. Thus, there is an increasing consensus on the need for a political and institutional framework that prevents the possible de-industrialization associated with inappropriate macroeconomic management and poor governance of NR. On that, Norway is often considered a case in point in the literature since it showed positive results in terms of industrial development from NR (although neo-structuralists and neo-institutionalists tend to emphasize different aspects of the Norwegian strategy).

7 Other authors outside ECLAC agree with Kuramoto's conclusions. See: Heum et al. (2003: 54); Morris et al. (2011); and Adewuyi and Oyejide (2012). 
In light of these considerations, we suggest that sound-development policies in resource-rich countries must combine two objectives: (1) to make consistent macroeconomic and industrial policy through proper management of exchange rates and monetary policy, which curb potential currency appreciation, and (2) to ensure the efficient use of resource rents in a way to combine both productive and social goals.

To achieve the first objective, most scholars have suggested allocating the resource rents to the creation of ad-hoc reserve funds with specific functions, although we found differences among authors on the priority given to them. The creation of such funds may contribute to disciplining current public expenditure while adding countercyclical financing needed to overcome the adverse effects of volatility. This may also serve to stabilize the exchange rate market by regulating currency supply.

However, close coordination among policymakers in fiscal and monetary policy is required, along with a stable institutional framework that clearly regulates the functioning of those funds.

Regarding the second objective proposed above (2), Torvik (2002) and Mehlum et al. (2006) have shown that in the case of oil-rich economies, the best performing countries were those that devoted the largest share of oil-related rents to productive investment. But as Cypher (2010) has stated, rents must also contribute 'to a reduction in income and wealth inequality in order to build effective demand for the internal market as well as to address the issue of economic justice' (Cypher, 2010: 646).

Overall, we found a widespread consensus that public expenditure management should be part of a prudent fiscal policy (Budina et al., 2006; Gianella, 2007; Lama and Medina, 2010; Baunsgaard et al., 2012). Some authors have gone further to promote the direct distribution of resource rents directly to citizens, with the government then forced to tax the distributed rents (Sala-i-Martin and Subramanian, 2003; Birdsall and Subramanian, 2004). However, the empirical evidence is still limited to the case of Alaskan citizens’ funds, and it is not clear whether developing countries have the institutional capacity to adopt these instruments as Alaska did (Hjort, 2006).

A key issue is to place the pursuit of the two goals mentioned above in the specific context of each economy. Fiscal and social policy, and particularly industry policy, must take into account the specific conditions of each economy, especially the factors that hold back the diversification of production, even with proper management of revenues toward the achievement of both goals. The already mentioned work of Pegg (2010) on Botswana is also illustrative of the influence of economic, social, cultural and even geographical 
local factors that have slowed the diversification of production. Moreover, the management of macroeconomic policy is not the only factor influenced by the external environment; industry is also conditioned by the dynamics of global and regional markets. This requires a recognition of limits on what can be achieved.

So far, seeking to overcome the problems identified in Section 2, we have discussed main issues affecting the use of resource rents, distinguishing between macroeconomic, productive, and social purposes. There still remains a crucial aspect to be discussed on which there is little consensus in the literature: the government taking on resource rents. What kind of governmental appropriation is necessary to achieve the macroeconomic, productive, and social objectives outlined above? Should this participation be the same regardless of the degree of presence of transnational companies and State-Owned Enterprises in the domestic economy? Experiences in this regard are broadly different, making it difficult to reach a universal answer. Nevertheless, we have found some interesting experiences in the oil and gas industry from which to draw some lessons.

On one hand, the Norwegian model, usually taken as an example of "good practices" in the literature, has been developed with a high degree of government participation in resource rents. This experience, together with the deficiencies encountered in some lowtaxing developing countries at the end of the 1990s, has led scholars to emphasize the importance and legitimacy of a higher government take. The aim would be to capture more rents for re-investment in favor of productive diversification or social programs. However, there is evidence that in several countries a higher in-take from national government does not necessarily guarantee a good fiscal performance. Indeed, these experiences motivate resource curse literature to propose stricter controls on public spending. ${ }^{8}$

As regards oil and gas industry, the Brazilian case may provide worthwhile elements to this discussion. The current model of exploration and exploitation of oil and gas reserves in that country has been developed with low government take and has generated interesting results in terms of production and processing of resources. However, this low

8 Some publications of the World Bank connect with this approach by emphasizing the need for transparency in the management of income and the quality of institutions (Canuto and Giugale, 2010: 113; Sinnott et al., 2010; De Rosa and Iootty, 2012). The Extractive Industries Transparency Initiative (supported by the Bank World, among others) is an attempt to apply a mod el of "good governance". However, Colom (2011) in a study of Ghana, emphasizes that though transparency is always desirable, there are problems related to the exploitation of NR 'that are not going to be solved only by applying more transparency' Colom (2011: 7). According to this author, there are issues having to do with the political economy of the country beyond the approach of transparency. 
public participation is only apparent since Petrobras retains a high percentage of the income generated in the exploitation of oil and gas; also, the use of that income is directly or indirectly influenced by the federal energy policy. This may explain the sharp rise of investments in refining of oil and gas, as well as the strengthening of Petrobras' policy on local suppliers since 2003, coinciding with the industrialization impulse intended by the federal government.

In an empirical research on 74 mineral export-dependent countries, Hinojosa et al. (2010) found a positive association between State revenue and social policy and conclude that resource rents could be used by the government as a springboard to launch social policies devoted to enhance social welfare. However, Weinthal and Jones Long (2006) have pointed out that the State's direct control on resource rents may lead to weak regulatory and fiscal institutions. Based on the case of the Russian oil and gas industry, the authors have argued that domestic private ownership may foster the incentives for both public and private actors to bargain over the establishment of strong institutions. Privatization creates clear boundaries between government actors and private owners, which impede the discretional use of rents by State elites.

The World Bank argues that resource extraction and good governance may together promote poverty reduction; hence, it would be possible to replicate a good governance model that has succeeded in one country within another. However, the evidence from the case of Chad-Cameroon pipeline project seems to contradict this argument (Pegg, 2006). The World Bank Group partially funded the pipeline and pushed for a model of good governance based on monitoring and good practices. ${ }^{9}$ However, the project suffered serious design flaws: the revenue management law allowed the president of Chad to modify, by unilateral decree, part of the revenue flow, which was diverted to military spending. In short, it seems that simply establishing a model of good governance may not ensure a resource-led development strategy.

In short, the model of management and distribution of resource rents between public and private actors should be closely linked to the institutional framework affecting their governance. Regardless of the degree of participation of public and private companies, on the fiscal dimension this model must ensure compliance of the two aforementioned objectives of a sound industrialization strategy.

9 It is worth noting that the World Bank has been pioneer in advocating for a "mining strategy" for Latin America and the Caribbean based on good institutions (World Bank, 1996). 


\section{Key Proposals}

The identification of the conditions to be met by an industrialization strategy should be based on a proper diagnosis of the obstacles that resource-rich countries have traditionally faced. Thus, the first part of this paper has focused on reviewing the literature to identify these problems, while the second part has analyzed the contributions that address some experiences of industrialization in countries with abundant NR from which we could identify the conditions that such a strategy should meet. The answer suggested below is intended to contribute to the current debate on the development strategies linked to the exploitation of NR but it cannot be regarded as conclusively true or rigidly applicable to all countries. On the contrary, it must be interpreted in light of the particularities of each economy and its specific development needs (Chang, 2003).

The article has shared and extended the contribution of other scholars who stressed the relevance of domestic policy decisions in determining the impact of the exploitation of NR. We argue that sound economic policies should take into account both fiscal and productive dimension. Taking into account the findings highlighted in the previous sections, we suggest that a resource-based industrialization strategy should be defined by four key features. These elements are interrelated and, as it is shown in the table 2, they can be grouped into two dimensions, the productive one and the fiscal one, as follows:

- Productive dimension

1) A sustained increase of production, which will form the material basis of the strategy. Such productive expansion is possible only through a concurrent steady increase in investments.

2) The development of the industrial value chain linked to the exploitation of natural resources (with backward and forward linkages), thereby correcting a primary productive and export pattern.

- Fiscal dimension

3) The use and management of resource rents to avoid the Dutch Disease, in coordination and complementarity with industrial and macroeconomic policy.

4) The allocation of resource rents to support social programs those allow a redistribution of income and a steady improvement in living conditions. 
Table 2. Conditions to foster industrial development from natural resources and problems to overcome

\begin{tabular}{|c|c|c|}
\hline Conditions & $\begin{array}{c}\text { Problems to } \\
\text { overcome }\end{array}$ & Select scholars \\
\hline \multirow[t]{3}{*}{$\begin{array}{l}\text { Productive } \\
\text { dimension }\end{array}$} & $\begin{array}{l}\text { To encourage } \\
\text { production and export } \\
\text { diversification to } \\
\text { overcome the dualism }\end{array}$ & $\begin{array}{lr}\text { Ramos } & \text { (1998); } \\
\text { Ritter } & \text { (2001); } \\
\text { Kaplinski et al. } \\
\text { (2011); Sæther et al. } \\
\text { (2011); ECLAC } \\
\text { (2005, 2008); UN- } \\
\text { ECA } \\
\text { UNIDO (2011); }\end{array}$ \\
\hline & $\begin{array}{lr}\text { Diversification } & \text { may } \\
\text { help to reduce } & \text { the } \\
\text { vulnerability } & \text { to } \\
\text { external shocks } & \end{array}$ & $\begin{array}{lr}\text { ECLAC } & (2005) ; \\
\text { Hausmann } & \text { and } \\
\text { Rodríguez (2006) }\end{array}$ \\
\hline & $\begin{array}{lr}\text { Acquisition } & \text { and } \\
\text { development } & \text { of } \\
\text { technological } & \text { and } \\
\text { human resources } & \\
\text { capabilities } & \end{array}$ & $\begin{array}{lr}\text { Buitelaar } & \text { (2001); } \\
\text { ECLAC } & \text { (2008); } \\
\text { Peek et al. (2008); } & \text { Teixeira and Ferraro } \\
\text { (2009); rérez } \\
\text { (2010); Morris et al. } \\
\text { (2011); Teka (2012) }\end{array}$ \\
\hline \multirow[t]{2}{*}{ Fiscal dimension } & \begin{tabular}{|lr} 
To make consistent \\
macroeconomic and \\
industrial policy \\
through a proper \\
management r of \\
exchange rates and \\
monetary policy
\end{tabular} & $\begin{array}{l}\text { Budina et al. (2006); } \\
\text { Gianella (2007); } \\
\text { Lama and Medina } \\
\text { (2010); Sinnott et al. } \\
\text { (2010); Baunsgaard } \\
\text { et al. (2012) }\end{array}$ \\
\hline & $\begin{array}{l}\text { The use of resource } \\
\text { rents in a way to } \\
\text { combine } \\
\text { productive and social } \\
\text { goals }\end{array}$ & $\begin{array}{ll}\text { AUC } & \text { (2009); } \\
\text { Cypher } & \text { (2010); } \\
\text { Hinojosa } & \text { et al. } \\
(2010) & \end{array}$ \\
\hline
\end{tabular}

The identification of these basic features entails an orderly and consistent assessment of the implementation of the strategy, to identify the potential constraints and contradictions. However, this does not imply that there is a single policy and a universal institutional framework for compliance with the four conditions. The growing literature on the governance ${ }^{10}$ of NR seeks to identify this setting by defining a model of good

10 The use of the term governance is increasingly common in the literature. However, it is not possible to identify a broad consensus based on a single definition. For ECLAC (2013), governance of NR is 
institutions applicable to all countries. The problem with such a generalization is that it makes it impossible to identify the conditions that have characterized the different historical experiences of many resource-rich countries (Findlay and Lundhal, 1999; Feinstein, 2005; Blomström and Kokko, 2007).

There are differences among scholars on the policy and the institutional factors necessary for achieving these conditions. The most important disagreements are found in the specification of the measures to implement the policies, and in defining the most appropriate ownership structure for promoting the industrialization. Starting with the latter, some authors, inheriting a neoliberal view, tend to consider that the exploitation of NR is more efficient when it is managed by the private sector (Sinnott et al., 2010). However, the empirical evidence is not conclusive on that point (Hertog, 2010), especially when the goal is not to reach a more intensive resource exploitation but rather to foster the industrialization. There is also little evidence on the benefits of the presence of StateOwned Enterprises whose performance is strongly influenced by their organizational and financial capabilities, as well as by the links with the countries in which they are inserted (Paz and Ramírez, 2013).

These examples suggest that the government may need to play an active role in mediating and establishing the institutional framework to enhance its participation in order to actively support domestic agriculture and rural small-scale industrialization. Hence, State-ownership or State-influence in specific enterprises may be seen as a strategic condition to foster industrial development, but only when this gives appropriate response to the country-specific structural characteristics.

Anyhow, whether or not in presence of a strong State-Owned Enterprise, transnational corporations are often key players in most regimes of exploitation of NR. Therefore, the regulatory framework of their activities should be considered as a strategic element to foster the industrial linkages. Not surprisingly, the more recent literature has revived the debate on the need to introduce performance requirements to foreign investors and local content policies (UNCTAD, 2003; UN-ECA, 2011).

With regard to industrial policy, neo-structuralists are noted for having a more favorable approach to it, as they believe that a development strategy linked to the NR should not be limited to a simple macroeconomic management, but it must be involved in the productive sphere. This more active role of industrial policy is absent in the neo- 
institutionalist approach, as its advocates tend to defend market mechanisms and the openness to private investments in the extractive sector. In our opinion, such a view ignores the implications of the liberalization according to the historical and structural characteristics of each country. Moreover, while the neo-institutionalist approach proposed more trade openness (Arezki and van der Ploeg, 2007), an increased external openness in the extractive sectors may have contradictory implications with certain measures intended to foster the domestic industrial development.

Finally, it is necessary to incorporate a reflection on the institutions. Although the institutional framework is considered a strategic element in all the interpretations we have analyzed here, there are significant differences in specifying the necessary institutions to sustain the economic policy. Scholars of the DD and the resource curse tend to consider that institutional quality is primarily tied to the protection of property rights as well as to the transparency and efficiency in the management of NR. The productive activities related to the exploitation of NR have been traditionally associated with an institutional decay; therefore, one should be wary of the role of government intervention. On the other hand, neo-structuralists consider that institutions can be understood only in relation to the specific characteristics of the productive structure of a country and its economic and social history. This view rejects the notion of a model of "good institutions" as being a prerequisite for economic development.

In sum, these disagreements illustrate what Rodrik (2013) has called the operational implications, which can be overcome with different institutional and policy patterns. It is only necessary that each model should be consistent with the structural preconditions of each country. Two examples relating to the fundamental dimensions outlined in this paper can be useful to illustrate our argument.

First, from a productive perspective, we have noted the usefulness of including local content measures to boost linkages between sectors and to overcome the enclave model typical of natural resource sectors. Different countries (including Angola, Brazil, Indonesia, Nigeria, and Trinidad and Tobago) have incorporated such measures; however, these are effective when local capabilities are minimal, and when the measures are articulated in coherence with a broader industrial policy (Tordo et. al, 2013; Adewuyi and Oyejide, 2012; Teka, 2012). The experience of many countries shows that a set of "easy" links can be fostered in low-tech activities, but that the development of medium and high technology activities is achieved only when the above conditions are met. Furthermore, in certain countries, this can only occur with the arrival of foreign capital, due to the lack 
of a local business base, and this can reinforce dependency in the development process (Evans, 1979). Finally, the importance of purely physical or geological features has been sometimes confirmed, such as in the case of Brazil, where a concentration of oil and gas reserves in ultra-deep waters has fostered linkages with the naval sector (Paz, 2014).

Second, from a fiscal perspective, the experience of the Russian Federation is a case in point. To face the economic crisis, amendments to the Budget Code of the Russian Federation were passed in 2010 to establish that, in 2010-2015, the oil and gas revenues of the federal budget would not be used to finance the Reserve Fund and National Wealth Fund, but be deployed to finance federal budget expenditures. ${ }^{11}$

Therefore, the acquisition of supportive institutions for structural change requires a process of experimentation and adaptation over time, which contrasts with a mere replication of a universal and static model of "good governance”.

\section{Concluding remarks}

This paper has attempted to identify the main problems associated with the exploitation of NR, with a focus on developing countries. We have found that the prominent literature addresses the issue from different perspectives, according to a variety of theoretical assumptions and conceptual frameworks. Scholars who focus on the DD and the resource curse tend to give special attention to the fiscal and macroeconomic aspects that affects economic growth. On the other hand, Latin American structuralists and neo-structuralists are more concerned with the investigation of the more complex process of structural change associated with the exploitation of NR. The empirical evidence seems to highlight that the materialization of most of the alleged problems related with NR is not automatic; that is, the resource curse is neither inevitable nor irreversible. On the contrary, its manifestation is the result of historical economic as well as political and institutional factors.

In coherence with the various problems analyzed, the literature assigns varying importance to the different measures that may contribute to fostering a resource-based industrialization. Rejecting a dogmatic position in favor of a model "good institutions", scholars coincide that an adequate institutional and political framework to foster industrial development structural change vary depending on the distinctive features of each given country. Coming from a perspective which attempts to integrate the more fruitful aspects

11 On the functioning of the sovereign wealth funds in Russia see Chevrier (2009). 
of both neo-institutionalism and Latin American structuralism, we have considered that the key issues at stake are essentially two: the industrial policy and the definition of the ownership structure of the NR.

In our opinion, in order to avoid an adherence to failing paradigms, it is necessary to go further in deepening into the investigation of case studies, especially at a time when the emergence of a new consensus in development economics are redefining the policies adopted by developing countries. Case studies may allow for the discovery of the critical implications of each of the conditions identified in this paper and help to define an industrial development strategy coherent with the necessities and the possibilities of each country. As we have shown, a proliferation of case studies has focused on the fiscal dimension of natural resource exploitation, whereas industrial development is a comparatively under-researched topic. Yet there has been increasing interest in studying the effects of local content policies in the oil and gas industry (Tordo et al., 2013). However, little attention has been paid to other initiatives promoted by the State to foster industrial development based on the exploitation of extractive industries. For instance, in the Brazilian oil and gas industry, oil companies are required to invest at least $1 \%$ of their gross revenue (generated by certain specific oilfields) in oil and gas-related research and development (R\&D). Up to half of the requirement may fulfilled at the companies' facilities in Brazil, while the rest goes toward funding research projects carried out by universities or research institutes.

Finally, it is worth pointing out some limitations of this paper related with the relatively scant attention paid to the field of Ecological Economics, which may be useful to define a less "productivist" approach to the exploitation of NR. The ecological dimension works cross-wise to the fiscal and the productive dimensions that we have identified. Moreover, further research on NR is needed from a gender perspective and the consideration of socio-environmental conflicts related with the exploitation of those resources. $^{12}$

\section{References}

Adewuyi, A. O. and Oyejide, T. A., 2012 Determinants of Backward Linkages of the Oil and Gas Industry in the Nigerian Economy. Resources Policy, 37 (4), 452-460.

12 See: Eftimie et al. (2009); and Ward et al. (2011). 
Andersen, J.J. and Ross, M.L., 2014. The Big Oil Change: A Closer Look at the HaberMenaldo Analysis. Comparative Political Studies, 47 (7), 993-1021.

Aragón, F.M. and Rud, J.P., 2011. Natural Resources and Local Communities: Evidence from a Peruvian Gold Mine. Yale University. New Haven, CT: Yale University.

Atkinson, G. and Hamilton, K., 2003. Savings, Growth and the Resource Curse Hypothesis. World Development, 31 (11), 1793-1807.

African Union Commission (AUC), 2009. Africa mining vision. Addis Ababa: AUC.

Auty, R.M., 1994. Industrial Policy Reform in Six Large Newly Industrializing Countries: the Resource Curse Thesis. World Development, 22 (1), 11-26.

Auty, R.M., 2001. The Political Economy of Resource-Driven Growth. European Economic Review 45 (4-6), 839-46.

Baunsgaard, T., Villafuerte, M., Poplawski-Ribeiro, M. and Richmond, C., 2012. Fiscal Frameworks for Resource Rich Developing Countries. IMF Staff Discussion Note SDN/12/04. IMF Washington, DC.

Bhattacharyya, S. and Resosudarno, B.P., 2015. Growth, Growth Accelerations, and the Poor: Lessons from Indonesia. World Development, 66, 154-165.

Birdsall, N. and Subramanian, A. 2004. Saving Iraq from its Oil. Foreign Affairs 83 (4), 77-89.

Blomström, M. and Kokko, A.F., 2007. From Natural Resources to High-Tech Production: the Evolution of Industrial Competitiveness in Sweden and Finland. In D. Lederman and W.F. Maloney (Eds.), Natural resources. Neither curse nor destiny, (pp. 213-256). Stanford Economics and Finance, Palo Alto, CA. The World Bank, Washington, DC

Bravo-Ortega, C. and De Gregorio, J., 2005. The Relative Richness of the Poor? Natural Resources, Human Capital and Economic Growth. World Bank, Policy Research Working Paper Series 3484. The World Bank, Washington, DC.

Brunnschweiler, C.N. and Bulte, E.H., 2006. The Resource Curse Revisited and Revised: A Tale of Paradoxes and Red Herrings. Center of Economic Research at ETH Zurich Economics Working Paper Series 06/61.

Brunnschweiler, C.N., 2008. Cursing the blessings? Natural resource abundance, institutions, and economic growth. World Development, 36 (3), 399-419.

Brunnschweiler, C.N. and Bulte, E.H., 2008. Natural Resources and Violent Conflict: Resource Abundance, Dependence and the Onset of Civil Wars. CER-ETH (Center of Economic Research at ETH Zurich). Economics Working Paper Series 08/78.

Bruno, M. and Sachs, J., 1982. Energy and Resource Allocation: a Dynamic Model of the 'Dutch Disease'. NBER Working Paper 852. NBER, Cambridge, MA.

Budina, N., Pang, G. and van Wijnbergen, S., 2006. Nigeria: Dutch Disease or Debt Overhang? Diagnosing the Past, Lessons for the Future. The World Bank, Washington, DC.

Buitelaar, R.M., (Ed.), 2001. Aglomeraciones Mineras y Desarrollo Local en América Latina. United Nations, Santiago de Chile.

Bulte, E., Damania, R., and Deacon, R., 2005. Resource intensity, institutions, and development. World Development, 33 (7), 1029-1044.

Caballero, R.J. and Lorenzoni, G., 2007. Persistent Appreciations and Overshooting: a Normative Analysis. NBER Working Paper 13077. NBER, Cambridge, MA.

Canuto, O. and Giugale, M. (Eds.) (2010). The Day after Tomorrow. A Handbook on the Future of Economic Policy in the Developing World. The World Bank, Washington DC.

Caselli, F. and Michaels, G., 2009. Do Oil Windfalls Improve Living Standards? Evidence from Brazil. NBER Working Paper 15550. NBER, Cambridge, MA. 
Chang, H.-J., 2003. Rethinking Development Economics: an Introduction". In H.-J. Chang (Ed.), Rethinking Development Economics, Anthem Studies in Development and Globalization. Anthem Press.

Chevrier, C., 2009. Sovereign Wealth Funds in Russia. Revue d'Économie Financière, 9 (1), 73-81.

Collier, P. and Hoeffler, A., 2004. Greed and Grievance in Civil War. Oxford Economic Papers 56 (4), 563-595.

Colom, A., 2011. La Iniciativa ITIE y sus Limitaciones en África: el Caso del Chad. Claves de la Economía Mundial, 1-7. ICEX-ICEI, Madrid.

Corden, W.M., 1984. Booming Sector and Dutch Disease Economics: Survey and Consolidation. Oxford Economic Papers, 36 (3), 359-380.

Corden, W.M. and Neary, J.P., 1982. Booming Sector and De-industrialisation in a Small Open Economy. The Economic Journal, 92 (368), 825-848.

Cypher, J.M., 2010. South America's Commodities Boom: Developmental Opportunity or Path Dependent Reversion? Canadian Journal of Development Studies, 30 (3-4), 635-662.

De Rosa, D. and Iootty, M., 2012. Are Natural Resources Cursed? An Investigation of the Dynamic Effects of Resource Dependence on Institutional Quality. The World Bank Policy Research Working Paper 6151. The World Bank, Washington, DC

Di John, J., 2011. Is There Really a Resource Curse? A Critical Survey of Theory and Evidence. Global Governance, 17, 167-184

United Nations Economic Commission for Latin America and the Caribbean (ECLAC), 2005. Aglomeraciones en torno a los recursos naturales en América Latina y el Caribe: Políticas de articulación y articulación de políticas. United Nations, Santiago de Chile.

ECLAC, 2008. La Transformación Productiva 20 Años Después. Viejos Problemas, Nuevas Oportunidades. J.L. Machinea (Coord.), United Nations, Santiago de Chile.

ECLAC, 2013. Recursos Naturales en UNASUR. Situación y Tendencias para una Agenda de Desarrollo Regional. United Nations, Santiago de Chile.

Eftimie, A., Heller, K. and Strongman, J., 2009. Gender Dimensions of the Extractive Industries: Mining for Equity. The World Bank Extractive Industries and Development Series, 8. The World Bank, Washington, DC.

Evans, P. 1979. Dependent development: the alliance of multinational, state, and local capital in Brazil. Princeton University Press, Princeton.

Feinstein, C.H., 2005. An Economic History of South Africa: Conquest, Discrimination and Development. Cambridge University Press, Cambridge.

Findlay, R. and Lundahl, M., 1999. Resource-Led Growth. A Long-Term Perspective. The Relevance of the 1870-1914 Experience for Today's Developing Economies. Working Paper 162. The United Nations University and World Institute for Development Economics Research (WIDER).

Furtado, C., 1968. Teoría y política del desarrollo económico. Siglo XXI, Madrid.

Fuentes, J.R., 2009. Managing Natural Resources Revenue: The Case of Chile. Oxford Centre for the Analysis of Resource Rich Economies. OxCarre Research Paper, 40.

Gianella, C., 2007. A Golden Rule for Russia? How a Rule-Based Fiscal Policy Can Allow a Smooth Adjustment to the New Terms of Trade. OECD Economics Department Working Papers 53715. OECD, Paris.

Gylfason, T., 2001. Lessons from the Dutch Disease: Causes, Treatment, and Cures. For: STATOIL-ECON conference "The Paradox of Plenty".

Gylfason, T., Herbertsson, T.T., and Zoega, G., 1999. A Mixed Blessing, Natural Resources and Economic Growth. Macroeconomic Dynamics. 3 (1999). 204-225. 
Haber, S. and Menaldo, V., 2011. Do Natural Resources Fuel Authoritarianism? A Reappraisal of the Resource Curse. American Political Science Review. 105(1), 1-26.

Hammond, J.L., 2011. The Resource Curse and Oil Revenues in Angola and Venezuela. Science and Society, 75(3), 348-378.

Hausmann, R. and Rodríguez, F., 2006. Why Did Venezuelan Growth Collapse? In R. Hausmann and F. Rodríguez (Eds.), 2006. Venezuela, Anatomy of a Collapse, Ch.2, Harvard University.

Hausmann, R. and Rodrik, D., 2002. Economic Development as Self-Discovery. NBER Working Paper 8952, May 2002 (revised March 2006). NBER, Cambridge, MA.

Hertog, S., 2010. Defying the Resource Curse Explaining Successful State-Owned Enterprises in Rentier States. World Politics, 62 (2), 261-301.

Heum, P., Quale, C., Karlsen, J.E., Kragha, M. and Osahon, G., 2003. Enhancement of Local Content in the Upstream Oil and Gas Industry in Nigeria. A Comprehensive and Viable Policy Approach. SNF Report 25/03.

Hinojosa, L., Bebbington, A., Barrientos, A. and Addison T., 2010. Social Policy and State Revenues in Mineral-Rich Contexts. United Nations Research Institute for Social Development (UNRISD), Social Policy and Development Programme Paper, 44.

Hirschman, A.O., 1964. The Strategy of Economic Development. Yale University Press, New Haven, London.

Hjort, J., 2006. Citizen Funds and Dutch Disease in Developing Countries. Resources Policy, 31 (3), 183-191.

Isham, J., Woolcock, M., Pritchett, L., and Busby, G., 2003. The Varieties of the Resource Experience: how Natural Resource Export Structures Affect the Political Economy of Economic Growth. Middlebury College Discussion Paper 2003-08.

Kaplinsky, R., Morris, M. and Kaplan, D., 2011. A Conceptual Overview to Understand Commodities, Linkages and Industrial Development in Africa.

Kim, Y.J., 1998. Resource Curse, Overcommitment, and Human Capital. Journal of Economic Development, 23 (2), 103-121.

Krugman, P., 1987. The Narrow Moving Band, the Dutch Disease and the Competitive Consequences of Mrs. Thatcher on Trade in the Presence of Dynamic Scale Economies. Journal of Development Economics, 27 (1-2), 41-55.

Kuramoto, J.R., 2000. Las Aglomeraciones Productivas Alrededor de la Minería: el Caso de la Minera Yanacocha S.A. ECLAC Serie Desarrollo Productivo 67. ECLAC, Santiago de Chile.

Lama, R. and Medina, J.P., 2010. Is Exchange Rate Stabilization an Appropriate Cure for the Dutch Disease? IMF Working Paper WP/10/182. IMF, Washington, DC.

Lederman, D. and Maloney, W.F., 2002. Open Questions About the Link Between Natural Resources and Economic Growth: Sachs and Warner Revisited. Central Bank of Chile Working Paper, 141.

Lederman, D. and Maloney, W.F., 2008. In Search of the Missing Resource Curse. The World Bank Policy Research Working Paper, 4766. The World Bank, Washington, DC.

Leite, C. and Weidmann, J., 1999. Does Mother Nature Corrupt? Natural Resources, Corruption, and Economic Growth. IMF Working Paper WP/99/85. IMF, Washington, DC.

Lippert, A.B., 2014. Spill-Overs of a Resource Boom: Evidence from Zambian Copper Mines. Oxford Centre for the Analysis of Resource Rich Economies. OxCarre Research Paper 131. 
Machinea, J.L, and Vera, C., 2007. Inserción Internacional y Políticas de Desarrollo Productivo. In J.L., Machinea and N. Serra (Eds), 2007. Visiones del desarrollo en América Latina. 341-405. ECLAC, Santiago de Chile; Fundación CIDOB, Barcelona.

Magud, N.E. and Sosa, S., 2010. When and Why to Worry About Real Exchange Rate Appreciation? The Missing Link between Dutch Disease and Growth. IMF Working Paper WP/10/271. IMF, Washington, DC.

Mehlum, H., Moene, K. and Torvik, R., 2006. Institutions and the Resource Curse. The Economic Journal, 116 (508), 1-20.

Morris, M., Kaplinsky, R., and Kaplan, D., 2011. Commodities and Linkages: Industrialisation in Sub Saharan Africa. MMCP Discussion Paper, 13.

Nurkse, R., 1953. Problems of Capital Formation in Underdeveloped Countries. Oxford University Press, Oxford.

Paz, M.J., and Ramírez, J.M., 2013. How Important Are National Companies for Oil and Gas Sector Performance? Lessons from the Bolivia and Brazil Case Studies. Energy Policy, 61, 707-716.

Paz, M.J., 2014. Oil and development in Brazil: Between and Extractive and an Industrialization Strategy, Energy Policy, 73, 501-511.

Peek, P., J.F., Gantes, P., and Theiler, C., 2008. Skills Shortages in the Global Oil and Gas Industry. How to Close the Gap, Part I. Centre de Recherches Entreprises et Sociétés (CRES).

Pegg, S., 2006. Can Policy Intervention Beat the Resource Curse? Evidence from the Chad-Cameroon Pipeline Project. African Affairs, 105 (418), 1-25.

Pegg, S., 2010. Is There a Dutch Disease in Botswana? Resources Policy, 35 (1), 14-19.

Pérez, C., 2010. Dinamismo Tecnológico e Inclusión Social en América Latina: una Estrategia de Desarrollo Productivo Basada en los Recursos Naturales. ECLAC Review, 100, 123-145. ECLAC, Santiago de Chile.

Prebisch, R., 1950. The Economic Development of Latin America and Its Principal Problems. Available at: $<$ http://repositorio.cepal.org/bitstream/handle/11362/30088/001_es.pdf?sequence=2>

Prebisch, R., 1981. Capitalismo Periférico: Crisis y Transformación. Fondo de Cultura Económica, Mexico.

Programa de Mobilização da Indústria Nacional de Petróleo e Gás Natural (Promimp) (2010) Potenciando o Desenvolvimiento da Industria Nacional. Available at: $<$ http://www.prominp.com.br/portal/prominp/pt br/documentos-gerais.htm>.

Ramos, J., 1999. Una Estrategia de Desarrollo a Partir de los Complejos Productivos (clusters) en torno a los Recursos Naturales ¿Una Estrategia Prometedora? United Nations, Santiago de Chile.

Ritter, A.R.M., 2001. La Aglomeración en Torno a la Minería en Canadá: Estructura, Evolución y Funcionamiento. In R.M. Buitelaar (ed), Aglomeraciones Mineras y Desarrollo Local en América Latina, (chapter II). United Nations, Santiago de Chile.

Robinson, J.A., Torvik, R., and Verdier, T., 2006. Political foundations of the resource curse. Journal of Development Economics, 79 (2), 447-68.

Ross, M.L., 1999. The Political Economy of the Resource Curse. World Politics, 51 (2), 297-322.

Ross, M.L., 2001. Extractive Sectors and the Poor. Oxfam America, Boston, MA.

Ross, M.L., 2004. What Do We Know About Natural Resources and Civil War? Journal of Peace Research, 41(3), 337-356.

Sachs, J.D., and Warner, A., 1995, revised 1997. Natural Resource Abundance and Economic Growth. NBER Working Paper 5398. NBER, Cambridge, MA. 
Sachs, J.D., and Warner, A., 2001. Natural Resources and Economic Development: the Curse of Natural Resources. European Economic Review, 45 (4-6), 827-838.

Sæther, B., Isaksen, A., and Karlsen, A., 2011. Innovation by Co-Evolution in Natural Resource Industries: the Norwegian Experience. Geoforum, 42 (2011), 373-381.

Sala-i-Martin, X., and Subramanian, A., 2003. Addressing the Resource Curse: an Illustration from Nigeria. NBER Working Paper 9804. NBER, Cambridge, MA.

Singer, H.W., 1950. U.S. Foreign Investment in Underdeveloped Areas: the Distribution of Gains between Investing and Borrowing Countries. The American Economic Review, 40 (2), 473-485.

Sinnott, E., Nash, J., and de la Torre, A., 2010. Natural Resources in Latin America and the Caribbean: Beyond Booms and Busts? The World Bank, Washington, DC.

Smith, B., 2007. Hard Times in the Lands of Plenty: Oil Politics in Iran and Indonesia. Ithaca: Cornell University Press.

Stevens, P., 2003. Resource Impact: a Curse or a Blessing. University of Dundee, Centre for Energy, Petroleum and Mineral Law and Policy.

Stijns, J.-P.C., 2000. Natural Resource Abundance and Economic Growth Revisited. University of California, Berkeley Department of Economics.

Teixeira, F., and Ferraro, C., 2009. Aglomeraciones Productivas Locales en Brasil, Formación de Recursos Humanos y Resultados de la Experiencia CEPAL-SEBRAE. ECLAC Serie Desarrollo Productivo, 186. United Nations, Santiago de Chile.

Teka, Z, 2012. Linkages to Manufacturing in the Resource Sector: the Case of the Angolan Oil and Gas Industry. Resources Policy, 37 (4), 461-467.

The World Bank, 1996. A mining strategy for Latin America and the Caribbean. The World Bank Technical Paper 345. The World Bank, Washington, DC.

Tordo, S., Warner, M., Manzano, O. and Anouti, Y., 2013. Local content policies in the oil and gas sector. A World Bank Study. Washington, DC: The World Bank.

Tornell, A., and Lane, P.R., 1999. The Voracity Effect. The American Economic Review, 89 (1), 22-46.

Torvik, R., 2002. Natural Resources, Rent Seeking and Welfare. Journal of Development Economics, 67 (2002), 455-470.

United Nations Conference on Trade And Development (UNCTAD), 2003. Foreign Direct Investment and Performance Requirements: New Evidence from Selected Countries. UNCTAD Document UNCTAD/ITE/IIA/2003/7. UNCTAD, New York and Geneva.

UNCTAD, 2011. Report of the Global Commodities Forum 2011. The Second Global Commodities Forum. UNCTAD Document UNCTAD/SUC/2011/5. UNCTAD, Geneva.

United Nations Economic Commission for Africa (UN-ECA), 2011. Minerals and Africa's Development. The International Study Group Report on Africa's Mineral Regimes. UN-ECA, Addis Ababa.

United Nations Industrial Development Organization (UNIDO), 2011. Commodities for Industrial Development: Making Linkages Work. UNIDO Working Paper 01/2011. (Prepared by: Kaplinsky, R.). The Open University.

van der Ploeg, F., 2010. Natural Resources: Curse or Blessing? Cesifo Working Paper, 3125. Category 9: Resource and Environment Economics.

van Wijnbergen, S., 1984. The Dutch Disease: a Disease after All? Economic Journal, 94 (373), 41-55.

Ward, B., Strongman, J., Eftimie, A., and Heller, K., 2011. Gender-sensitive Approaches for the Extractive Industry in Peru. Improving the Impact on Women in Poverty and 
their Families: Guide for Improving Practice. The World Bank Extractive Industries and Development Series, 24. The World Bank, Washington, DC.

Weinthal, E. and Jones Luong, P., 2006. Combating the Resource Curse: an Alternative Solution to Managing Mineral Wealth. Perspectives on Politics, 4 (1), 35-53.

Wright, G., and Czelusta, J., 2002. Exorcising the Resource Curse: Minerals as a Knowledge Industry, Past and Present. Stanford University Working Paper, 2008. 